Al-Manhaj: Jurnal Hukum dan Pranata Sosial Islam

Vol. : : 2 (1), 2020, 45-64

P-ISSN : 2686-1607

E-ISSN : 2686-4819

\title{
METODE PENYELESAIAN TA'ARUDH AL-ADILLAH DALAM METODOLOGI HUKUM ISLAM
}

\author{
Khoirul Fathoni \\ Institut Agama Islam Negeri Ponorogo \\ Institut Agama Islam Sunan Giri Ponorogo \\ Email: khoirulfathoni@iainponorogo.ac.id
}

\begin{abstract}
The efforts of mujtahids in exploring the law are certainly not as easy as we imagine. Often they find difficulties because our legal basis is sometimes miraculous. Not infrequently there is a conflict between the arguments of one with another argument, which in ushul fiqh is called ta'arudh al adillah. Usul experts mutually engaged in trying to solve the problem. In this paper, we will discuss the meaning of ta'arudh al adillah and how the method of completion is done. And also components related to ta'arudh, such as nasakh mansukh, 'amm khash, muthlaq muqayyad, and lughawiyyah rules. This paper is in the form of descriptive, which describes the meaning of ta'arudh and how to solve it, and also matters relating to the efforts to complete ta'arudh. The author concludes that ta'arudh are two propositions, each of which denies what is pointed out by other propositions. There are two methods that are put forward in this paper, namely the Hanafiyah method and the Mutakallimin method or Jumhur Ulama. According to them there are four ways in completing ta'arudh, namely nasakh, tajih, al jam'u wa al taufiq, and tasaqut al dalilain.
\end{abstract}

Keywords: Method, Ta'arudh, Rule, Law

Abstrak: Usaha para mujtahid dalam menggali hukum tentu saja tidak semudah yang kita bayangkan. Sering kali mereka menemukan kesulitan karena dasar hukum kita yang kadang bersifat mujmal. Tidak jarang terjadi pertentangan antara dalil satu dengan dalil lain, yang dalam ushul fiqh disebut ta'arudh al adillah. Para ahli ushul saling berijtihad dalam usaha memecahkan permasalahan tersebut. Dalam tulisan ini akan dibahas tentang pengertian ta'arudh al adillah berikut bagaimana metode penyeleseiannya. Dan juga komponen-komponen yang berhubungan dengan ta'arudh, seperti nasakh mansukh, 'amm khash, muthlaq 
muqayyad, dan kaidah lughawiyyah. Tulisan ini berbentuk deskriptif, yaitu mendeskripsikan pengertian ta'arudh serta cara penyeleseiannya, dah juga hal-hal yang berhubungan dalam usaha penyeleseian ta'arudh. Penulis memberi kesimpulan bahwa ta'arudh ini sebagai dua dalil yang masing-masing menafikan apa yang ditunjuk oleh dalil lain. Ada dua metode yang penulisan kemukakan dalam tulisan ini, yaitu metode Hanafiyah dan metode Mutakallimin atau Jumhur Ulama. Menurut mereka ada empat cara dalam menyeleseikan ta'arudh, yaitu nasakh, tajih, al jam'u wa al taufiq, dan tasaqut al dalilain.

Kata kunci: Metode, Ta'arudh, Kaidah, Hukum

\section{PENDAHULUAN}

Islam sebagai agama yang aturannya mencakup berbagai aspek, tentunya mempunyai dasar-dasar pijakan dalam menentukan hukum yang lazim dikenal dengan masadhir alahkam al-syar'iyah (sumber-sumber hukum syara'). Tidak satupun yang ter-alpakan dalam agama ini. Termasuk dalam permasalahan hukum dimana hukum Islam mempunyai karakteristik syumuliyah atau kamaliyah.

Tingkat intelektualitas seseorang dalam memahami dalildalil syara' terkadang menimbulkan adanya sebuah pertentangan antara satu dalil dengan dalil lain dalam benaknya. Pertentangan ini menjadi fakta yang sulit untuk dihindari oleh seorang mujtahid, yang kemudian dari kalangan ushuliyin merumuskan metode untuk mencarikan solusi apabila terdapat ta'arudh al adillah.

Para ahli ushul membuat metode dalam menyelesaikan ta'arudh al adillah, masing-masing dari metode yang mereka tawarkan mencakup berbagai teori bahasan fan ushul fiqh yang membutuhkan kejelihan dalam memahaminya. Sehingga, perlu 
adanya pembahasan khusus pada teori-teori tersebut sebelum memahami ta'arudh al adillah itu sendiri. Tulisan ini berbentuk deskriptif, yaitu mendeskripsikan pengertian ta'arudh serta cara penyeleseiannya, dah juga hal-hal yang berhubungan dalam usaha penyeleseian ta'arudh.

\section{TA'ARUDH AL ADILLAH}

Menurut bahasa arudh berarti taqabul dan tamanu' atau bertentangan dan sulitnya pertemuan. Ulama ushul mengartikan ta'arud ini sebagai dalil yang masing-masing menghendaki hukum diwaktu yang sama terhadap satu kejadian yang menyalahi hukum yang dikehendaki oleh dalil yang lain. Misalnya ada ayat yang mewajibkan kita membuat wasiat untuk orang tua dan kerabat (al Baqarah: 178). Namun di lain pihak hadis melarang wasiat itu kepada ahli waris.

Contoh lain adalah membasuh atau menyapu kedua kaki ketika berwudhu. Hal ini terdapat dalam firman Allah surat al Maidah ayat 6:

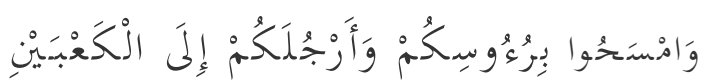

Dan sapulah kepalamu dan (basuh) kakimu sampai dengan kedua mata kaki.

Dalam satu qiraat dibaca wa arjulakum sehingga ada ulama yang berpendapat bahwa kaki itu wajib dibasuh ketika berwudhu. Namun, dalam qiraat lain dibaca wa arjulikum sehingga ada ulama yang mengatakan bahwa kaki itu cukup disapu saja ketika berwudhu. 
Begitu juga status mani yang menempel di kain. Dalam sebuah hadis nabi berkata bahwa mani itu sama hukumnya dengan lendir hidung dan air liur. Namun, di pihak lain ada lagi hadis yang menyatakan bahwa kain perlu dicuci dari lima hal: kencing, berak, darah, muntah, dan mani.

Banyak lagi contoh yang mengungkapkan ta'arud dalam lafad nash, sehingga berbeda pendapat dan sikap ulama dalam memahaminya. Namun, perlu dicatat bahwa ta'arud yang sebenarnya tidak mungkin terjadi dalam diri nash itu sendiri, sebab pertentangan seperti itu berarti pertentangan dalam diri syari', terutama Allah sendiri. Hal ini tentu mustahil adanya karena Allah bersih dari segala macam konflik batin sebagaimana terdapat dalam diri manusia. Oleh karena itu, ta'arud disini perlu dipahami sebagai pertentangan dalam nash menurut tanggapan manusia ketika mereka memahami nash itu sendiri. Oleh karena manusia tidak mungkin mengetahui kebenaran hakiki dan mutlak sebagaimana adanya dalam konsep Allah, pertentangan tersebut hanyalah semata-mata keterbatasan manusia dalam menangkap pesan-pesan syar'i yang sedang mereka pelajari. Dan menyadari keadaan semua ini, para ulama berusaha melepaskan diri dari pertentangan itu dengan menempuh dua jalan, yaitu jalan Hanafiyah dan jalan jumhur ulama. ${ }^{1}$

Macam-macam ta'arudh yaitu: (1) Ta'arudh antara al Quran dengan al-Quran, (2) Ta'arudh antara Sunnah dengan Sunnah, (3) 2006), 142.

${ }^{1}$ Alaiddin Koto, Ilmu Fiqh dan Ushul Fiqh (Jakarta: PT. Raja Grafindo Persada, 
Ta'arudh antara Sunnah dengan Qiyas, (4) Ta'arudh antara Qiyas dengan Qiyas. $^{2}$

\section{PENYELESEIAN TA'ARUD AL ADILLAH MENURUT HANAFIAH}

Ulama Hanafiyah mengatakan bahwa ta'arud bisa terjadi antara nash-nash syara' ataupun ta'arud antara dalil-dalil selain nash. Ta'arud yang terjadi pada dalil-dalil selain nash, semisal ta'arud antara dua qiyas, maka waijb bagi seorang mujtahid untuk mentarjih kedua qiyas tersebut dengan mengutamakan salah satunya.

Apabila pertentangan terjadi antara dua nash, para ulama Hanafiyah berpendapat bahwa metode-metode yang digunakan dalam menyelesaikannya secara sistematis adalah sebagai berikut: 1. Nasakh

Dari metode ini, seorang mujtahid harus melacak sejarah dari kedua nash, dan ketika sudah diketahui mana yang lebih dahulu datang dan mana yang datang kemudian, maka nash yang datang kemudian hukumnya menasakh yang terdahulu. Contohnya seperti pertentangan yang terjadi dalam dua ayat 'iddah dalam QS. Al-Baqarah (2): 234 dengan QS. Al-Thalaq (65): 4.

Sahabat Ibnu Mas'ud, kaitannya dengan permasalan dua ayat 'iddah tersebut menjelaskan bahwa ayat kedua (QS. Al-Thalaq (65): 4) yang datang kemudian me-nasakh hukum yang terkandung dalam ayat pertama (QS. Al-Baqarah (2): 234). 
Menjelaskan pendapat Ibnu Mas'ud dalam masalah ini, Dedi Supriyadi menguraikan sebagai berikut:

QS. Al-Baqarah (2) ayat 234 mencakup perempuan yang ditinggal mati oleh suaminya dalam keadaan hamil maupun tidak, sedangkan QS. Ath-Thalaq (65) ayat 4 hanya mengenai perempuan yang ditinggal mati oleh suaminya dalam keadaan hamil. Menurut Ibnu Mas'ud, QS. Al-Baqarah (2) ayat 234 turun lebih dahulu dan QS. Ath-Thalaq (65) ayat 4 turun kemudian. Oleh karena itu, Ibnu mas'ud berpendapat bahwa ayat terdahulu mansukh oleh ayat yang turun kemudian, yang lebih tepat adalah QS. Ath-Thalaq (65) ayat 4 membatasi (takhsis) keumuman makna QS. Al-Baqarah (2) ayat 234 .

\section{Tarjih}

Tarjih adalah menguatkan salah satu dalil dari dua dalil yang bertentangan berdasarkan beberapa qorinah yang mendukung ketetapan tersebut. Apabila dua dalil yang bertentangan sulit dilacak sejarahnya oleh seorang mujtahid, maka mujtahid tersebut harus me-rajih-kan salah satu dalil ketika memungkinkan. Pen-tarjih-an bisa menggunakan beberapa metode tarjih. Semisal menguatkan nash yang muhkam dari pada nash yang mufassar, menguatkan dalil yang mengandung hukum haram dari dalil yang mengandung hukum boleh, dan dari segi 'adalah, dhabit, faqih dan sebagainya seorang perawi hadits. ${ }^{3}$

${ }^{3}$ Dedi Supriyadi, Sejarah Hukum Islam, dari Kawasan Jazirah Arab sampai Indonesia (Bandung: Pustaka setia, 2007), 83. 
3. Al-Jam wa al-Taufiq

Al-jam'u wa al-taufiq yaitu mengompromikan dalil-dalil yang bertentangan setelah mengumpulkan keduanya, hal ini berdasarkan kaidah "mengamalkan kedua dalil lebih baik daripada meninggalkan atau mengabaikan dalil yang lain"4. Misalnya firman Allah swt., dalam surat al-Maidah (5): 3:

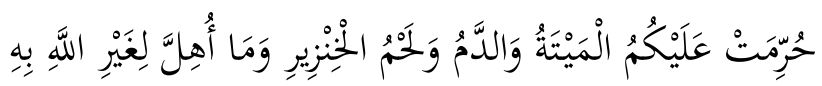

Diharamkan bagimu (memakan) bangkai, darah, daging babi, (daging hewan) yang disembelih atas nama selain Allah...

Ayat diatas tidak menjelaskan tentang jenis darah dan tidak membedakan antara darah yang mengalir dengan darah yang sudah beku. Kemudian ada ayat lain dalam surat al-An'am (6): 145: kecuali kalau makanan itu bangkai, atau darah yang mengalir. Pengompromian dari kedua ayat tersebut bahwa darah yang dilarang adalah darah yang mengalir.

4. Tasaqut al-Dalilain

Tasaqut al-dalilain adalah langkah terakhir mujtahid yang berarti menggugurkan kedua dalil yang bertentangan dan mencari yang lebih rendah. Hal ini ditempuh apabila tidak bisa menggunakan ketiga cara diatas. Misalnya ada pertentangan antara dua ayat, sedang tata cara sebelumnya sangat sulit dipakai, maka langkah yang harus ditempuh adalah mengambil keterangan yang lebih rendah dari al-Quran, yaitu Sunah. Apabila ada dua sunah yang bertentangan maka beralih pada istidlal dengan qoul 
al-sahabah bagi yang menggunakannya sebagai hujjah dan beralih pada qiyas bagi yang tidak menggunakan istidlal qoul al-Sahabat.

\section{MENURUT SYAFI'IYYAH}

Menurut Syafi'iyah, apabila terjadi pertentangan antara dua qiyas maka yang dilakukan seorang mujtahid adalah men-tarjih salah satu qiyas. Kemudian apabila terjadi pertentangan atau ta'arud antara dua nash dalam pandangan seorang mujtahid menurut madzhab Syafi'iyah, malikiyah, Hanabilah, dan Zhahiriyah wajib bagi mujtahid untuk melakukan pembahasan dan berijtihad sesuai dengan tahapan-tahapan berikut ini secara tertib. 1. Al-Jam'u wa al-Taufiq

Menurut aliran Syafi'iyah cara pertama untuk menyelesaikan dua dalil yang bertentangan adalah dengan mengompromikan kedua dalil tersebut. Ketika memungkinkan untuk mengompromikan, maka sudah seharusnya keduanya diamalkan dan tidak boleh men-tarjih salah satu antara keduanya. Argumentasi mereka adalah bahwa mengamalkan dua dalil yang bertentangan lebih utama daripada mendisfungsikan salah satu dalil secara keseluruhan. Cara yang digunakan untuk mengompromikan kedua dalil tersebut ada tiga: (1) Membagi kedua hukum yang bertentangan. (2) Memilih salah satu hukum. (3) Mengambil dalil yang lebih khusus, misalnya tentang masa 'iddah wanita hamil. Yang menurut Hanafiyah menggunakan metode nasakh. 


\section{Tarjih}

Apabila tidak bisa menggunakan metode al jam'u wa taufiq, seorang mujtahid beranjak pada tahapan selanjutnya, yaitu tarjih, yakni menguatkan salah satu dalil.

\section{Nasakh}

Ketika cara tarjih tidak dapat memberikan jawaban atas ta'arud baina al-adillah, maka melangkah pada nasakh. Yakni membatalkan hukum yang terkandung dalam dalil yang terdahulu dan mengamalkan hukum pada dalil yang turun kemudian.

\section{Tatsaqut al-Dalilain}

Langkah terakhir yang ditempuh apabila seorang mujtahid merasa kesulitan menyelesaikan pertentangan antar dalil ialah Tatsaqut al-dalilain. Yakni meninggalkan dalil-dalil yang bertentangan dan beralih pada dalil yang lebih rendah derajatnya.

\section{'AM KHASH, MUTHLAQ MUQAYYAD, DAN NASAKH MANSUKH}

Dari awal telah kita bicarakan bahwa rujukan utama dalam hukum islam adalah al Quran dan Hadis. Dua sumber ini telah diyakini dan disepakati oleh segenap ulama islam sebagai pegangan utama dan umat islam tidak akan tersesat selamalamanya selama mereka tetap berpegang kepada dua sumber tersebut. Namun kenyataan menunjukkan bahwa kedua sumber dimaksud terdiri dari lafad-lafad bahasa arab yang dalam suku katanya mempunyai arti banyak, dimana antara arti satu dengan 
yang lain saling bertentangan, atau ada banyak kata tetapi mempunyai arti yang sama. Selanjutnya ada lafad yang dari satu sisi dipandang sebagai hakikat, tetapi disisi lain dianggap sebagai majaz, ada lafad dalam bentuk muthlaq, dan ada yang muqayyad, ada yang 'am dan ada juga yang khash, nasakh mansukh. ${ }^{5}$

1. 'Amm dan Khass

'Amm adalah lafad yang menghabiskan atau mencakup segala apa yang pantas baginya tanpa ada pembatasan. ${ }^{6}$ Sementara itu ulama Hanafiyah memberikan definisi lain sebagai berikut: lafad 'amm ialah suatu lafad yang mencakup arti secara keseluruhan, baik dengan menggunakan lafad seperti rijal atau menggunakan isim mausul yang menunjukkan arti jamak, atau isim syarat dan yang seumpama dengannya, seperti lafad qaum, jin, atau ins serta lafad-lafad lain yang menunjukkan arti jamak. ${ }^{7}$ Adapun macam-mcam 'amm ada 3: (1) 'Amm yang tetap dalam keumumannya. 'Amm ini tidak mengandung kekhususan, seperti dalam surat Kahfi ayat 49. (2) 'Amm yang dimaksud khusus, seperti dalam surat Ali 'Imron ayat 173. (3) 'Amm yang dikhususkan. 'Amm macam ini banyak ditemukan dalam al Quraan, misalnya dalam surat al Baqarah ayat 187. Sedangkan Khass adalah lawan kata dari 'amm, karena ia tidak menghabiskan semua

${ }^{5}$ Alaiddin Koto, Ilmu Fiqh dan Ushul Fiqh, 137.

6 Manna' Khalil al Khattan, Studi Ilmu-ilmu a- Quran, terj. Mudzakkir AS (Bogor: Pustaka Litera Antar Nusa, 2001), 312.

7 Muhammad Abu Zahrah, Ushul Fiqih, terj. Saefullah Ma'shum (Jakarta: Pustaka Firdaus, 2010), 236. 
apa yang pantas baginya tanpa pembatasan. Takhsis adalah mengeluarkan sebagian apa yang dicakup lafad ' $a m m .^{8}$

2. Muthlaq Muqayyad

Muthlaq adalah lafad yang menunjukkan suatu hakikat, tanpa sesuatu taqyid (pembatas). Jadi ia hanya menunjuk pada satu individu tidak tertentu dari hakikat tersebut. Lafad muthlaq ini pada umumnya berbentuk lafad nakirah dalam konteks kalimat positif. Oleh karena itu sebagian ulama ushul mendefinisikan muthlaq dengan suatu ungkapan tentang isim nakirah dalam konteks positif. Kata-kata nakirah mengecualikan isim ma'rifah dan semua lafad yang menunjukkan sesuatu yang tertentu. Dan kata-kata dalam konteks positif mengecualikan isim nakirah dalam konteks negatif, karena nakirah dalam konteks negatif mempunyai arti umum, meliputi semua individu yang termasuk jenisnya.

Sedangkan muqayyad adalah lafad yang menunjukkan suatu hakikat dengan qayyid (batasan). ${ }^{9}$ Para fuqaha' telah bersepakat bahwa jika ada lafad muthlaq yang hukum dan objeknya sama dengan lafad yang muqayyad, maka pengertian lafad yang muthlaq tersebut disesuaikan dengan lafad yang muqayyad. Misalnya dalam surat al Maidah ayat 3:

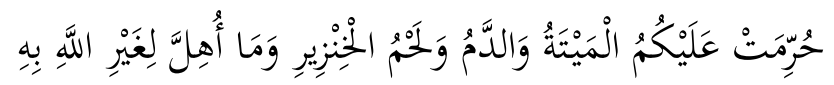

Diharamkan bagimu (memakan) bangkai, darah, daging babi, (daging hewan) yang disembelih atas nama selain Allah.

Darah yang disebutkan dalam ayat diatas adalah bersifat mutlak. Oleh karena itu, pengertian darah yang bersifat mutlak 
tersebut disesuaikan dengan pengertian darah yang muqayyad dalam surat al An'am ayat 145:

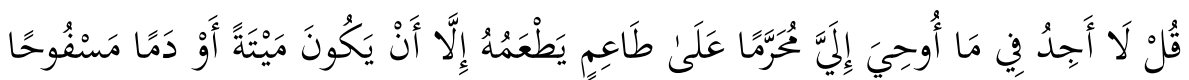

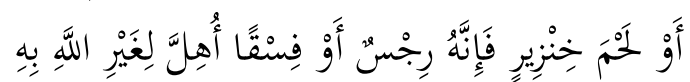

Katakanlah: "Tiadalah Aku peroleh dalam wahyu yang diwahyukan kepadaku, sesuatu yang diharamkan bagi orang yang hendak memakannya, kecuali kalau makanan itu bangkai, atau darah yang mengalir atau daging babi - Karena Sesungguhnya semua itu kotor - atau binatang yang disembelih atas nama selain Allah.

Berhubung objek kedua lafad tersebut sama, yakni darah, dan hukum keduanya sama yaitu diharamkan, maka pengertian lafad yang muthlaq tersebut disesuaikan dengan lafad yang muqayyad. Dengan demikian, darah yang diharamkan adalah darah yang mengalir. Adapun hati dan limpa tidak diharamkan karena tidak termasuk dalam kriteria darah yang mengalir.

Para ulama telah bersepakat bahwa apabila ada lafad muthlaq mempunyai perbedaan hukum dengan lafad yang muqayyad maka pengertian lafad yang muthlaq tidak dapat disesuaikan dengan lafad yang muqayyad, meskipun keduanya mempunyai sebab yang sama, kecuali apabila ada indikasi (qarinah) atau dalil lain yang tersendiri. Misalnya dalam surat al Maidah ayat 6:

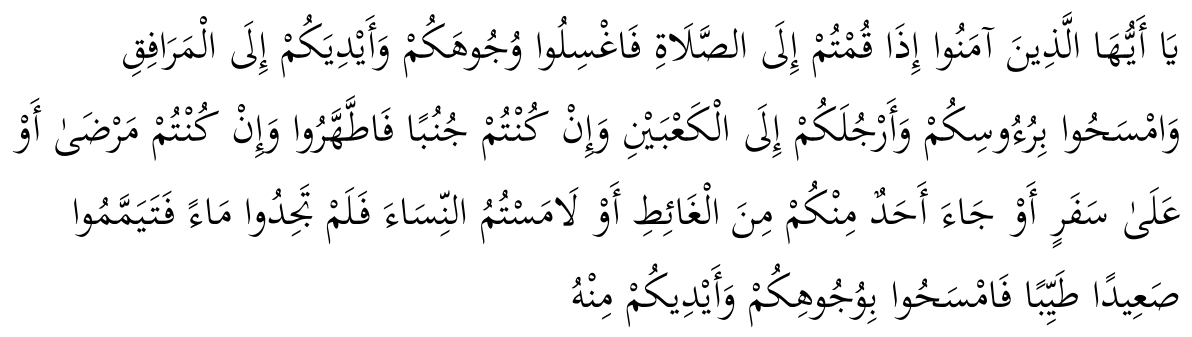


Hai orang-orang yang beriman, apabila kamu hendak mengerjakan shalat, Maka basuhlah mukamu dan tanganmu sampai dengan siku, dan sapulah kepalamu dan (basuh) kakimu sampai dengan kedua mata kaki, dan jika kamu junub Maka mandilah, dan jika kamu sakit atau dalam perjalanan atau kembali dari tempat buang air (kakus) atau menyentuh perempuan, lalu kamu tidak memperoleh air, Maka bertayammumlah dengan tanah yang baik (bersih); sapulah mukamu dan tanganmu dengan tanah itu.

Dalam ayat tersebut terdapat dua hukum yang berbeda, yakni kewajiban membasuh kedua tangan ketika berwudhu dan bertayammum. Kalau kewajiban membasuh kedua tangan dalam berwudhu dibatasi (muqayyad) hingga siku, sedang dalam bertayammum tidak dibatasi (muthlaq). Padahal yang menjadi penyebab mengerjakan wudhu dan tayammum adalah sama, yaitu mengerjakan shalat. Permasalahannya sekarang apakah kewajiban mengusap kedua tangan dalam bertayammum yang bersifat muthlaq itu dapat disesuaikan dengan kewajiban membasuh kedua tangan dalam berwudhu yang bersifat muqayyad lantaran keduanya mempunyai sebab yang sama?

Para fuqaha' telah menetapkan bahwa lafad yang muthlaq tersebut tidak dibawa pada lafad yang muqayyad. Sedangkan kewajiban mengusap kedua tangan sampai kedua siku dalam bertayammum adalah berdasarkan dalil lain yaitu sabda Rasulullah SAW: Tayammum itu dilakukan dengan dua kali usapan, sekali mengusap muka, dan sekali mengusap kedua tangan sampai dengan siku. ${ }^{10}$

10 Muhammad Abu Zahrah, Ushul Fiqih, terj. Saefullah Ma'shum (Jakarta: Pustaka Firdaus, 2010), 260. 


\section{Nasakh Mansukh}

Nasakh menurut bahasa dipergunakan untuk arti izalah (menghilangkan). Kata nasakh juga dipergunakan untuk makna memindahkan sesuatu dari suatu tempat ke tempat lain. Sedangkan menurut istilah nasakh ialah mengangkat (menghapuskan) hukum syara'dengan dalil hukum syara' yang lain. ${ }^{11}$

Untuk menasakh suatu nash disyaratkan harus memenuhi empat syarat berikut ini: (1) Hukum yang dimansukh tidak diikuti oleh ungkapan yang menunjukkan atas berlakunya hukum tersebut selama-lamanya. Misalnya sabda Nabi SAW; Jihad tetap berlangsung sampai hari kiamat. (2) Hukum yang dimansukh itu tidak termasuk masalah-masalah yang telah disepakati oleh para cerdik pandai atas kebaikan atau keburukan masalah-masalah tersebut. Seperti beriman kepada Allah SWT, berbuat baik kepada orang tua, jujur, adil, menganiaya, bohong dan sebagainya. (3) Nash yang mengganti turunnya harus lebih akhir dari nash yang diganti. Disamping itu kedua nash diatas harus sama kekuatannya. (4) Jika nash tidak jelas maka disyaratkan kedua nash tersebut benar-benar sudah tidak dapat dikompromikan.

Nasakh terbagi menjadi dua macam, yaitu: (1) Nasakh sharih, ialah nasakh yang menyatakan dengan jelas bahwa hukum yang dimansukh telah habis masa berlakunya. Misalnya sabda Nabi SAW: Dahulu aku telah melarang kalian untuk berziarah kubur. Oleh karena (sekarang) berziarahlah kamu sekalian ke 
kuburan. (2) Nasakh Dhimmi, ialah mengganti salah satu dari dua nash yang saling berlawanan dan keduanya tidak dapat dikompromikan. Nasakah Dhimmi dibagi menjadi dua, yaitu: (a) Nasakh Dhimmi yang mengganti seluruh hukum yang terkandung dalam nash yang turunnya lebih dahulu. Misalnya dalam surat al Baqarah ayat 234:

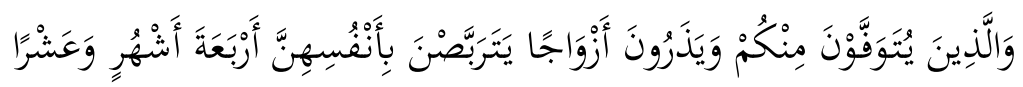

Orang-orang yang meninggal dunia di antaramu dengan meninggalkan isteri-isteri (hendaklah para isteri itu) menangguhkan dirinya (ber'iddah) empat bulan sepuluh hari.

Ayat diatas mengganti huku-hukum yang terkandung dalam surat al Baqarah ayat 240:

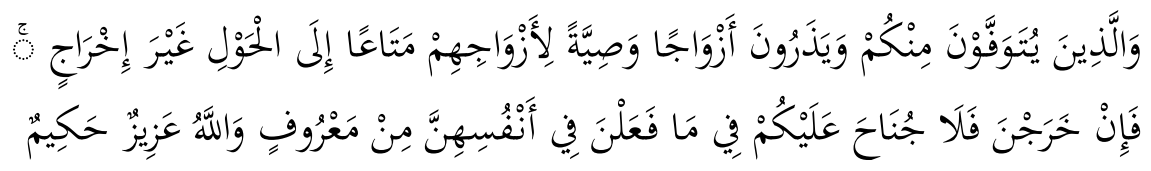

Dan orang-orang yang akan meninggal dunia di antara kamu dan meninggalkan isteri, hendaklah berwasiat untuk isteriisterinya, (yaitu) diberi nafkah hingga setahun lamanya dan tidak disuruh pindah (dari rumahnya). akan tetapi jika mereka pindah (sendiri), Maka tidak ada dosa bagimu (wali atau waris dari yang meninggal) membiarkan mereka berbuat yang ma'ruf terhadap diri mereka. dan Allah Maha Perkasa lagi Maha Bijaksana.

(b)Nasakh Dhimmi yang mengganti sebagian hukum yang terkandung dalam suatu nash. Misalnya dalam surat an-Nur ayat 4:

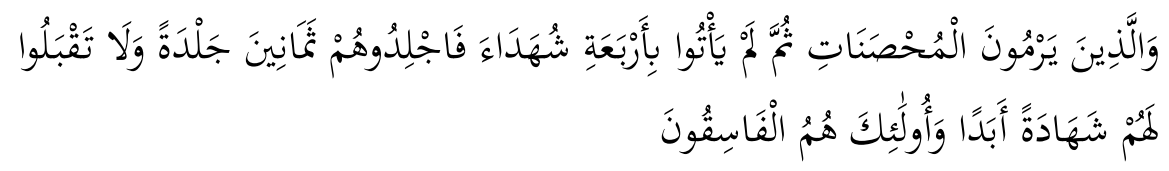

Dan orang-orang yang menuduh wanita-wanita yang baikbaik (berbuat zina) dan mereka tidak mendatangkan empat orang saksi, Maka deralah mereka (yang menuduh itu) delapan puluh kali 
dera, dan janganlah kamu terima kesaksian mereka buat selamalamanya. dan mereka Itulah orang-orang yang fasik.

Keumuman ayat diatas dinasakh oleh ayat yang menjelaskan tentang sanksi seorang suami yang menuduh isterinya berbuat zina dalam surat an-Nur ayat 6:

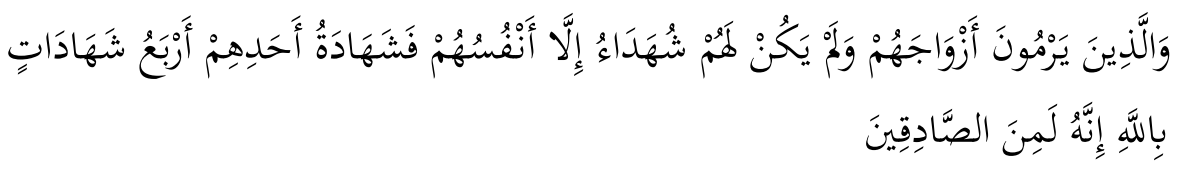

Dan orang-orang yang menuduh isterinya (berzina), padahal mereka tidak ada mempunyai saksi-saksi selain diri mereka sendiri, Maka persaksian orang itu ialah empat kali bersumpah dengan nama Allah, Sesungguhnya dia adalah termasuk orang-orang yang benar. ${ }^{12}$

\section{KAIDAH USHUL TASYRI'IYYAH DAN USHUL LUGHAWIYYAH}

1. Kaidah ushul tasyri'iyyah

Kaidah tasyri'iyyah adalah kaidah-kaidah yang bertalian dengan tujuan dan dasar-dasar syara' dalam menetapkan hukum. Kaidah-kaidah itu dipetik setelah melalui penelitian terhadap hukum-hukum syariat beserta hikmahnya, illat beserta sebabsebab disyari'atkannya suatu hukum, dan prinsip beserta jiwa atau hakikat syariat itu sendiri. Kaidah-kaidah itu dirumuskan untuk diketahui dan dipedomani oleh siapa saja yang bermaksud untuk menafsirkan nash-nash tasyri'.

Sebagai pedoman untuk melakukan aktifitas tersebut, para pemikir ilmu hukum islam menetapkan serangkaian kaidah yang mengatakan bahwa: (a) Al Quran adalah sumber hukum utama 
dan hadis adalah sumber hukum kedua. (b) Peristiwa atau kasuskasus yang hukumnya telah ditunjuk secara jelas oleh nash tidak boleh lagi ditetapkan hukumnya berdasarkan analisis logika. (c) Peristiwa atau kasus-kasus yang hukumnya telah ditunjuk secara jelas oleh nash,tetapi tidak qath'i dalalahnya ditetapkan hukumnya berdasarkan ijtihad, baik melalui ijtihad kolektif (jama'i) maupun ijtihad perorangan (fardi). (d) Keputusan ijtihad kolektif harus didahulukan pengalamannya dari hasil ijtihad perorangan. (e) Kerangka utama ijtihad adalah qiyas atau prinsip memelihara orang banyak.

Perlu dicatat bahwa prinsip utama dari kaidah-kaidah tasyri'iyyah adalah berkisar upaya untuk memelihara jiwa syariat islam dalam menetapkan hukum untuk mewujudkan keadilan, kebenaran, persamaan, dan lain sebagainya.

Banyak memang kaidah yang telah dirumuskan oleh para pemikir hukum islam terdahulu untuk maksud-maksud diatas dan sebagai pedoman berijtihad.

Kaidah-kaidah itu antara lain:

a.

$$
\text { لايجوز لأحد أن يتصرف ملك الغير بلا إذنها وبلا و لاية }
$$

Tidak boleh bagi seseorang berkuasa terhadap milik orang lain tanpa izin atau pemberian kekuasaaan dari orang yang bersangkutan.

b.

$$
\text { تغير الأحكام بتغير الأزمان و الأمكنة و الأحو ال }
$$

Hukum itu bisa berubah dengan berubahnya zaman, tempat, dan situasi.

c.

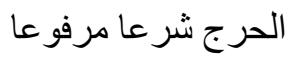

Kepicikan itu perlu diangkatkan.

d.

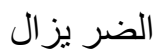

Kemudharatan itu perlu dihindari (dihilangkan). 
e. الأمور بمقاصدها

Semua urusan itu tergantung motifasinya.

f.

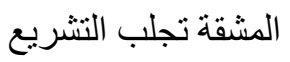

Kesulitan itu membawa kemudahan.

g.

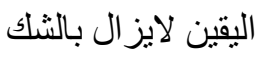

Keyakinan itu tidak dihilangkan oleh yang syak.

2. Kaidah ushul lughawiyyah

Yang dimaksud kaidah lughawiyyah adalah kaidah yang dirumuskan oleh para ulama berkaitan dengan maksud dan tujuan ungkapan-ungkapan bahasa arab yang lazim digunakan oleh bangsa arab itu sendiri, baik yang terdapat dalam ungkapanungkapan sastra, seperti syair, prosa dan lain sebagainya. ${ }^{13}$

Artinya nash-nash al Quran dan Hadis adalah bahasa arab. Untuk memahami hukum-hukum yang terkandung di kedua nash tersebut secara sempurna dan benar para ulama merasa perlu untuk memperhatikan dan melakukan penelitian tentang uslubuslub (gaya bahasa) arab tersebut serta meneliti cara penunjukkan lafad nash kepada arti yang ditujunya. Dari penelitian ini mereka menyusun kaidah-kaidah dan ketentuan-ketentuan yang dapat dipergunakan untuk memahami nash syariat secara tepat sesuai dengan pemahaman orang arab sendiri, terutama sekali ketika wahyu diturunkan. Kaidah-kaidah itu antara lain:

a.

الأصل فى الكليمة الحقييقة

${ }^{13}$ Mu'in Umar, Ushul Fiqh jilid II (Jakarta: Depag RI 1986), 2. 
Pada dasarnya pengertian dari suatu kalimat adalah hakikatnya.

b.

$$
\text { إذا تعذرت الحقيقة يصار إلى المجاز }
$$

Bila pengertian hakikat tidak bisa diterapkan maka dialihkan kepada pengertian majazi.

c.

إذا تعذر المجاز يهمل

Bila kalimat itu tidak bisa diartikan (menurut arti yang semestinya) maka ia dianggap kosong saja.

d.

$$
\text { الأصل فى الأمر للوجوب }
$$

Pada dasarnya kalimat perintah itu menunjukkan wajib.

e.

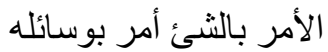

Perintah terhadap sesuatu berarti perintah juga terhadap cara-cara yang mengantarkan kepada sesuatu tersebut.

f.

$$
\text { الأصل فى النهي للتحريم }
$$

Pada dasarnya kalimat larangan itu menunjukkan haram.

g.

$$
\text { الأمر بعد النهي للأباحة }
$$

Perintah yang datang sesudah larangan menunjukkan kebolehan saja (bukan wajib).

Banyak lagi kaidah-kaidah lain yang jumlahnya cukup beragam, sesuai dengan penelitian para ulama masing-masing. Kaidah-kaidah itu dapat dilihat dari berbagai kitab ilmu ushul fiqih, baik yang disusun oleh imam-imam madzhab atau ulama-ulama dan kemudian pengikut mereka. ${ }^{14}$

\section{KESIMPULAN}

Menurut bahasa arudh berarti taqabul dan tamanu' atau bertentangan dan sulitnya pertemuan. Ulama ushul mengartikan ta'arudh ini sebagai dua dalil yang masing-masing menafikan apa

${ }^{14}$ Alaiddin Koto, Ilmu Fiqh dan Ushul Fiqh, 152. 
yang ditunjuk oleh dalil lain. Pada hakikatnya tidak ada pertentangan atau ta'arudh diantara dlil-dalil. Apabila ta'arudh terjadi, itu hanya secara lahiriyah dan tidak lain adalah kelemahan dari seorang mujtahid dalam memahami nash-nash syar'i. Apabila terdapat pertentangan antara dalil-dalil syara' dalam pandangan mujtahid, maka wajib baginya untuk melakukan pembahasan, analisis dan ijtihad terhadap dalil-dalil yang terlihat kontradiksi tersebut. Adapun metode atau cara menyelesaikan ta'arudh al adillah terdapat dua pandangan yang diwakili oleh kalangan Hanafiyah dan Mutakallimin atau Jumhur. Menurut Hanafiyah, solusi penyeleseian ta'arudh secara sistematis adalah sebagai berikut: Nasakh, Tarjih, Al-jam wa al-taufiq, Tasaqut al-Dalilain. Sedangkan menurut Jumhur ketika terjadi ta'arudh harus diselesaikan dengan tahapan-tahapan berupa: Al-jam'u wa altaufiq, Tarjih, Nasakh, Tatsaqut al-dalilain. Ada juga beberapa hal yang harus dipahami dalam menyeleseikan ta'arudh, antara lain 'amm khash, muthlaq muqayyad, dan qawa'id al lughawiyah.

\section{DAFTAR PUSTAKA}

Al-Khattan, Manna' Khalil. Studi Ilmu-ilmu al-Quran. terj. Mudzakkir AS. Bogor: Pustaka Litera Antar Nusa, 2001. Koto, Alaiddin. Ilmu Fiqh dan Ushul Fiqh. Jakarta: PT. Raja Grafindo Persada, 2006.

Supriyadi, Dedi. Sejarah Hukum Islam, dari Kawasan Jazirah Arab sampai Indonesia. Bandung: Pustaka setia, 2007.

Syafe'i, Rahmat. Ilmu Ushul Fiqh. Bandung: Pustaka Setia, 1998. Umar, Mu'in. Ushul Fiqh jilid 1. Jakarta: Depag RI 1985. Zahrah, Muhammad Abu. Ushul Fiqih. terj. Saefullah Ma'shum. Jakarta: Pustaka Firdaus, 2010. 